\title{
First Mapping Experiment of the Infrastructure \& Facility Asset Management Knowledge Developement in JMAIF and Reflexion on Scientific Paper Stipulation for JMAIF
}

\author{
Percobaan Pertama Pemetaan Pembangunan Pengetahuan Manajemen \\ Aset Infrastruktur \& Fasilitas di JMAIF dan Pemikiran tentang \\ Ketentuan Makalah Ilmiah bagi JMAIF
}

\author{
Hitapriya Suprayitno $^{1, a)}$ \& Ria Asih Aryani Soemitro ${ }^{1, b)}$ \\ ${ }^{1)}$ Civil Engineering Department, Institut Teknologi Sepuluh Nopember (ITS), Surabaya.
}

Correspondance : ${ }^{\text {a) }}$ suprayitno.hita@gmail.com \& ${ }^{\text {b) }}$ soemitroraa@gmail.com.

\begin{abstract}
Infrastructure \& Facility Asset Management knowledge need to be developed. JMAIF has been established, among others, to develop this knowledge. Knowledge Development Framework has been proposed. A mapping experiment need to be executed. The experiment shows, that among the 6 knowledge blocks, it is only 4 blocks which are filled. Three actions need to be executed : writting 5 Basic Knowledge in sequence, improving the Framework and executing Cross Mapping. Paper stipulation concerns scientific requirement and paper type needed. Sientific requirements are based on fact, logic, new, never been published. Types of scientific paper needed for JMAIf are : idea paper, characteristic paper, profesional experience paper, research paper, review paper.
\end{abstract}

Keywords : infrastructure \& facility asset management, knowledge development, mapping

\section{INTRODUCTION}

It has been discussed a lot in many occasions, that Infrastructure \& Facility (I\&F) are fundamnetal for Region's Life. It is capital to well build, to well operate and to well maintain the I\&F, for the shake of the Region's Life Quality and Development. Therefore, the I\&F Asset Management (I\&FAM) need to be well implemented and well developed (Geddes \& Congera 2016; Graser \& Leanage 2017; Soemitro \& Suprayitno 2018, Suprayitno \& Soemitro 2018).

In Indonesia, the Good I\&FAM Practices and Knowledges need to be promoted and developed. A Scientific Journal has been established, the JMAIF - Jurnal Manajemen Aset Infrastruktur \& Fasilitas, to promote and to develop the I\&FAM Practice and Knowledge. For the knowledge development a Framework for Developing the I\&FAM Knowledge has been formulated (Soemitro \& Suprayitno 2018; Suprayitno \& Soemitro 2018). This still need to be developed, through utilisation test, upon the existing JMAIF knowledge accumulation.

The knowledge development in JMAIF is a result of accummulation of knowledges written in published JMAIF papers. It is important then, to define what kind of scientific papers are needed for JMAIF, in order to be able to well develop the I\&FAM Knowledge..

This paper present an experiment to use the Framework to measure the advancement of knowledge development written in JMAIF and a reflexion on scientific paper stipulation needed by JMAIF to develop I\&FAM Knowledges. 


\section{RESEARCH METHOD}

The general research method follows these steps : background statement, objective formulation, mapping experiment, reflexion on paper stipulation, and finished by conclusions.

The Mapping Experiment consists of putting the published paper into the 7 Knowledge Frameworks. Thus, it consists of developing List of Papers and putting the Papers into the 7 Framework, means 7 Mappings.

Reflexion on Scientific Paper Stipulation must consists of stipulation on scientific requirement and paper types. The stipulation must be formulated based on the JMAIF objective to develop the I\&FAM knowledge and the fact that I\&FAM and JMAIF is still brand new. It will generate various informations needed and the trustworthy level needed.

\section{LITERATURE REVIEW}

I\&FAM Knowledge Development Framework has been proposed. It consists of 1 Knowledge Basic Structure and 6 groups of Basic Knowledges (Suprayitno \& Soemitro 2018). Those 7 Knowledges Framework are as follows.

- I\&FAM Knowledge Basic Structure

- I\&F Basic Knowledge

- I\&F Managing Organization Basic Knowledge

- I\&F Asset Management Basic Knowledge

- Organization Management Basic Knowledge

- Tools for Analysis Basic Knowledge

- Computer Aided Software Basic Knowledge

Various Types of Scientific Paper have ever been identified. For references those various types of scientific paper are presented below. For efficiency reason, explanation of each paper type are not written here and can be read in the source paper (Sterken 2006).

- Research Paper

- Letter to the Editor

- Information Bulletins

- Review Paper

- Essays

- Data Paper

- Instrument and Software Manual

- Invited Talk in Conference

- Contributed Paper in Conference

- Conference Paper

- Ticket Paper

- Publicity Paper

- Salami Paper

- Hoax Article

- Article in Mass Media

- Karaoke Paper

\section{KNOWLEDGE DEVELOPMENT MAPPING}

\section{Papers for Mapping Experiment}

As the first attempt, this I\&FAM Knowledge Development Mapping Experiment was executed upon I\&FAM papers published in the last four JMAIF editions. Totally, there are 16 papers published in 4 JMAIF editions. These 4 JMAIF editions are : 
- JMAIF, Vol. 1, No. 1, Desember 2017

- JMAIF, Vol. 2, No. 2, Maret 2018

- JMAIF, Vol. 2, Sup. 1, Juni 2018

- JMAIF, Vol. 2, No. 2, September 2018

Among the sixteen papers published in the last four JMAIF editions, one paper (V2N2P5) present the I\&FAM Knowledge Development Framework, and 15 other papers present various aspects of I\&FAM (Guamaradewi \& Mangundjaya 2018; Razif 2018; Soemitro \& Suprayitno 2018; Soemitro \& Suprayitno 2018a; Suprayitno \& Soemitro 2017; Suprayitno \& Soemitro 2018; Suprayitno \& Soemitro 2018a; Suprayitno \& Soemitro 2018b; Susnti, Soemitro \& Suprayitno 2017; Susanti, Soemitro \& Suprayitno 2018; Upa, Suprayitno \& Ryansyah 2018; Wibisono \& Donny 2018; Widiyanti et al 2017; Widiyanti et al 2018; Zanuardi \& Suprayitno 2018; Ziantono \& Suprayitno 2018). The distribution of the 16 papers into different topics is presented in Table 1 below.

Table 1. List of 16 Papers published in the Last Four JMAIF Editions

\begin{tabular}{|c|c|c|c|c|}
\hline No. & Vol. & No. & Paper & Title \\
\hline 1 & \multirow{3}{*}{$\mathrm{V} 1$} & \multirow{3}{*}{ N1 } & $\mathrm{P} 1$ & $\begin{array}{l}\text { Preliminary Attempt for Optimizing Transportation Vehicle Number in } \\
\text { General Case of Transporting Objects from n Origin Points to } 1 \text { Collection } \\
\text { Point }\end{array}$ \\
\hline 2 & & & $\mathrm{P} 2$ & $\begin{array}{l}\text { Characteris itcs of Reclaimed Asphalt Metarial form National Roads in East } \\
\text { Java Province }\end{array}$ \\
\hline 3 & & & $\mathrm{P} 3$ & $\begin{array}{l}\text { Simulation Method for Calculating Number of Seat Needed for Ticket } \\
\text { Reservation Facilities }\end{array}$ \\
\hline 4 & \multirow{5}{*}{$\mathrm{V} 2$} & \multirow{5}{*}{ N1 } & $\mathrm{P} 1$ & $\begin{array}{l}\text { Preliminary Reflexion on Basic Principle of Infrastructure As set } \\
\text { Management }\end{array}$ \\
\hline 5 & & & $\mathrm{P} 2$ & Optimization of Loading Arrangement of $\mathrm{n}$ Boxes into $\mathrm{m}$ Trnas portation Box \\
\hline 6 & & & $\mathrm{P} 3$ & $\begin{array}{l}\text { Identification of Station Facilities Needed by Train Passenger Based on } \\
\text { Passenger Movement Analysis }\end{array}$ \\
\hline 7 & & & P4 & $\begin{array}{l}\text { Performance of Asphalt Concrete Contained Reclaimed Asphalt Pavement } \\
\text { from National Road in East Java Province }\end{array}$ \\
\hline 8 & & & P5 & $\begin{array}{l}\text { Analys is of Traffic Accident Analys is on Ahmd Yani Road Surabaya } \\
\text { through Knowledge Discovery in Database Approach }\end{array}$ \\
\hline 9 & \multirow[b]{2}{*}{$\mathrm{V} 2$} & \multirow[b]{2}{*}{ S1 } & $\mathrm{P} 1$ & Preliminary Reflexion on Basic Concept of Facility Asset Management \\
\hline 10 & & & $\mathrm{P} 2$ & $\begin{array}{l}\text { Formulating a Policy for Developing Regional Solid Waste Final Disposal } \\
\text { Installation in East Java Province }\end{array}$ \\
\hline 11 & \multirow{6}{*}{ V2 } & \multirow{6}{*}{$\mathrm{N} 2$} & $\mathrm{P} 1$ & $\begin{array}{l}\text { The Impact of Individual and Organizational Readiness to Change on } \\
\text { Affective Commitment to Change }\end{array}$ \\
\hline 12 & & & $\mathrm{P} 2$ & $\begin{array}{l}\text { Comparaison and Synthese of Travel Behavior Characteristics between } \\
\text { Trans Mamminasata Bus and Trans Koetaradja Bus Users }\end{array}$ \\
\hline 13 & & & $\mathrm{P} 3$ & $\begin{array}{l}\text { Role of Environmental Aspects in Infrastructure and Facility Asset } \\
\text { Management }\end{array}$ \\
\hline 14 & & & $\mathrm{P} 4$ & $\begin{array}{l}\text { Study of Correlation between Coefficient of Determination with Prediction } \\
\text { Error for Certain Sample Size on Trip Production Model in Gresik Urban Area }\end{array}$ \\
\hline 15 & & & P5 & $\begin{array}{l}\text { Developing a Framework for Infrastructure Asset Management Knowledge } \\
\text { Development by Using Concept Mapping }\end{array}$ \\
\hline 16 & & & P6 & $\begin{array}{l}\text { Inters ection Traffic Performance at Kalen-Majenang due to the } \\
\text { Constructuion of Secondary Irrigation Channel of Bengawan Solo River in } \\
\text { Kedung Pring Distric, Lamongan }\end{array}$ \\
\hline
\end{tabular}




\section{Mapping of I\&FAM Knowledge Basic Structure}

The first step of mapping is putting the 15 papers into the 6 components of the I\&FAM Knowledge Basic Structure. One paper, V2N2P5 is excluded from this mapping, since it serve as a Framework for the Mapping Experiment. The mapping indicates that three papers discuss the knowledge on I\&F, one paper discuss knowledge on Managing Organization, 8 papers discuss knowledge on the I\&FAM, 3 papers discuss knoeledge on the Tools for Analyse. There is no paper dicussing the Organization Management aspects and the Computer Aided Software aspect. This first Mapping is presented in the Table 2 below.

Table 2. Mapping of I \& FAM Knowledge Basic Structure

\begin{tabular}{llc}
\hline Block & Paper & Number \\
\hline Infrastructure \& Facility & V1N1P2, V2N1P3, V2N1P4 & 3 \\
Managing Organization & V2N2P1 & 1 \\
Infrastructure \& Facility Asset Management & V2N1P1, V2N1P5, V2S1P1, V2S1P2, & 8 \\
Organization Management & V2N2P3, V2N2P2, V2N2P4, V2N2P6 & 0 \\
Tools for Analysis & - & 3 \\
Computer Aided Software & V1N1P1, V1N1P3, V2N1P2 & 0 \\
\hline
\end{tabular}

It can be seen very clearly that papers discusing the Basic Knowledge of Organization Management and Computer Aided Software need to be written soon and published in the following JMAIF edition. A Basic Knowledge on Computer Aided Software related to I\&FAM must be added to the Knowledge Basic Structure..

\section{Mapping of I\&F Basic Knowledge}

There are only three papers presenting knowledge on Infrastructure \& Facility. Those three present a deep infrastructure knowledges on road infrastructure and train station. Two paper present the characteristics of certain reclaimed asphalt, the other present the train station facility needed by the passengers. The contents of those three papers are mapped in Table 3 below.

Table 3. Papers on I \& F Basic Knowledge

\begin{tabular}{lcc}
\hline Family & \multicolumn{2}{c}{ Transportation } \\
\hline \multirow{2}{*}{ Group } & Road Transportation & Railway Transportation \\
\cline { 2 - 3 } Type & Flexible Pavement & Train Station \\
\hline Characteristics & - & - \\
\cline { 2 - 3 } Paper & V1N1P2, V2N1P4 & - \\
\hline
\end{tabular}

The Basic Knowledges of the Road Infrastructure and the Train Station are not yet revealed. Paper especially written to present the I\&F General Taxonomy Hierarchy and an example of I\&F Basic Characteristics need to be written.

\section{Mapping of Managing Organization Basic Knowledge}

Only one paper found on Managing Organization. It discus deep knowledge of organizational behavior. Paper discussing Basic Knowledge on Managing Organization need to be written and published soon.

\section{Mapping of I \& FAM Basic Knowledge}

There are 8 papers that can be classified presenting I\&FAM Knowledge. Two papers present the Basic Principle of Infrastructure Asset Management and the other present the Basic Concept of Facility Asset Management. One paper discuss I\&F Policy for Solid Waste 
Processing Facility. Two papers present the Planning step, deep about Infrastructure Demand. Two papers present the Infrastructure Operation aspect, deep about traffic safety and traffic performance. Another paper discuss the Environmental aspect, deep about the obligation to execute Environmental Impact Analysis.

Tabel 4. Paper on I \& FAM Knowledge

\begin{tabular}{llc}
\hline Step & Paper & Number \\
\hline Basic Principle & V2N1P1, V2S1P1 & 2 \\
I\&F Policy & V2S1P2 & 1 \\
I\&F Idea & - & 0 \\
I\&F Planning & V2N2P2, V2N2P4 & 2 \\
I\&F Design & - & 0 \\
I\&F Construction & - & 0 \\
I\&F Administration & - & 0 \\
I\&F Certification & - & 0 \\
I\&F Operation & V2N1P5, V2N2P6 & 2 \\
I\&F Maintenance & - & 0 \\
I\&F Disposal & - & 0 \\
I\&F Evaluation & - & 0 \\
Environmental Aspects & V2N2P3 & 1 \\
Spatial Aspect & - & \\
Regulation Aspect & - & 0 \\
\hline \multicolumn{2}{l}{} \\
\hline
\end{tabular}

Basic Principle on I\&FAM has been written in two papers. The idea still need to be improved, but not necesarily to be in hurry. Environmental, Spatial Aspects need to be added in I\&FAM Basic Knowledge Framework. The improvement paper on this Basic Principle of I\&FAM can be postponed until 1-2 years more, to collect enough improvement idea. On the other hand, papers on Basic Knowledges on each I\&FAM steps and each I\&FAM aspects need to be written and published soon. It can be noted that an example of developing an I\&F Policy has been written and published.

\section{Mapping of Organization Management Basic Knowledge}

Paper on Organization Management can not be found. Since Knowledge on Organization Management is very important and basic, paper on Basic Knowledge of Organization Management need to be written and published soon.

\section{Mapping of Tools for Analysis Basic Knowledge}

There are only three papers discussing Tools for Analyse. Two papers can be catagorized as discussing optimization problem, thus can be classified as papers on operation research. The other one present about simulation method. The paper distribution into topics is presented in Tabel 5 below.

Tabel 5. Paper on Tools for Analysis

\begin{tabular}{ll}
\hline Topics & Paper \\
\hline Operation Research & V1N1P1, V2N1P2 \\
Simulation & V1N1P3 \\
\hline
\end{tabular}

It can be seen clearly that paper dicussing Basic Knowledge on Tools for Analyse is not yet published. It needs to be written and published soon. 


\section{Mapping of Computer Aided Software Basic Knowledge}

There is no paper discusing Computer Aided Software. This knowledge is very important as now we are in Generation 4.0 Industry. A paper discussing the Basic Knowledge on Computer Aided Software related to I\&FAM need to be written and published soon.

\section{I\&FAM Knowledge Development Action Needed}

Three group of actions needed have been found after the mapping, i.e. 5 Basic Knowledge paper in priority, the framework improvement and the need to do Cross Mapping between the I\&F Type and the Knowledge Components.

Since the Basic Principle of I\&FAM has been written, there are still 5 Basic Knowledges to be written and published as priority. Those 5 are presented below.

- Basic Knowledge on Infrastructure \& Facility

- Basic Knowledge on I\&F Managing Organization

- Basic Knowledge on Organization Management

- Basic Knowledge on Tools for Analysis

- Basic Knowledge on Computer Aided Software

I\&FAM Knowledge Development Framework improvement : Knowledge Basic Structure, I\&FAM added by Environmental and Spatial aspects. Improvement needed for the other Knowledge Framework cannot be found, since paper on these is not yet written.

\section{Scientific Paper Stipulation for JMAIF as Journal for I\&FAM Knowledge Development}

I\&FAM is new in Indonesia. JMAIF is the first Indonesian Scientific Journal. So knowledgement development in JMAIF is strated from zero. Knowledge development need informations on : I\&FAM definition, basic principle and basic knowledge on I\&FAM, I\&FAM profesional problematics, I\&FAM charactersitics, etc.

Knowledge development is an accumulation of knowledges written in published JMAIF paper. To fulfill the above needs of knowledges, the papers published in JMAIF must be scientific paper. Thus it needs two principal stipulations : scientific requirements and paper types (Mark 2018; Reis \& Reis 2013; Sterken 2006).

JMAIF Scientific Paper requirements is formulated as follows : written in JMAIF template, linguistically good, no plagiarism, based on facts (not hoaxed), correlations among different parts are logic, a new idea compared the exisitng JMAIF content, refer to at least 1 JMAIF paper and 1 jurnal paper non JMAIF.

Due to the fact that JMAIF and the I\&FAM is still new in Indonesia, any kind of I\&FAM true and logic informations are still neded for I\&FAM Knowledge Development. Therefore, the 5 types of paper needed is formulated below.

- Idea Paper.

Paper presenting any new idea about I\&FAM : basic principle, policy, planning principle, design principle, operation principle, maintenance principle, model, etc.

- Information Paper on I\&FAM Objects Characteristics.

Paper presenting any characteristics of I\&FAM objects. It can be any I\&F physical objects or conceptual objects.

- Profesional Experience Paper.

Paper presenting any kind and any view of I\&FAM profesional experiences scientifically.

- Review Paper.

Paper presenting summarized and synthesized different ideas of I\&FMA written on scientific journal, hand-book or any article..

- Research Paper. 
Paper presenting revealing I\&FAM still hidden fact, concerning characteristics, method, model, etc.

\section{CONCLUSIONS}

The experiment and reflexion have been finished well. The objective has been achieved. Several principle conclusions are written below.

- The Mapping Experiment has been finished. The 15 papers can fill 5 Basic Knowledge frameworks, but not the Organization Management and Computer Aided Software. Even if the 5 frameworks have been filled, general overview of the 5 Basic Knowledge Framewroks are not yet written.

- Five papers on Basic Knowledge need to be written soon : Infrastructure \& Facility, I\&F Managing Organization, Organization Management, Tools for Analysis, Computer Aided Software.

- I\&FAM Knowledge Development Framework improvement needed : add Computer Aided Software to the I\&FAM Knowledge Basic Structure, add Environmental and Spatial aspects to the I\&FAM Basic Knowledge.

- Next mapping should be done in Cross Mapping between I\&F Type and Basic Knowledge aspects.

- Two JMAIF Scientific Paper basic stipulations consist of 7 paper requirements and 5 paper types.

Basic Principle of I\&FAM has been written. Therefore, further imminent steps needed for I\&FAM Knowledge Development in JMAIF are the 5 Basic Knowledges on Infrastructure \& Facility, Managing Organization, Organization Management, Tools for Analysis and Computer Aided Software. JMAIF should execute an arrangement, so that papers on Infrastructure \& Facility and on Managing Organization must be prioritized. Afterward, papers on Basic Knowledge of Organization Management, of Tools for Analysis and of Computer Aided Software must follow. While paper on examples of each of steps and each aspects of I\&FAM could follow afterward.

Notes. This paper is part of Basic Steps for Developing \& I\&FAM Knowledge. This paper will be systematically written once annually or bi-annually, to check the lack of Basic Knowledges needed for the I\&FAM Knowledge Development in JMAIF.

\section{REFERENCES}

Geddes, R. \& Gongera, K. (2016). "Economic Growth through Effective Road Asset Management". International Conference on Transport and Road Research, 16th - 18th March 2016, Whitesands Hotel. Mombasa.

Graser, D. \& Leanage, L. (2017). Realizing Social and Economic Objectives through Infrastructure Planning and Investment. Final Report. Evergreen.

Guamaradewi, N.G. \& Mangundjaya, W.L. (2018). "The Impact of Individual and Organizational Readiness to Change on Affective Commitment to Change". Jurnal Manajemen Aset Infrastruktur \& Fasilitas, Vol. 2, No. 2, September 2018, Hal. : 57-67.

Mark, C.A. (2018). How to Write a Good Scientific Paper. SPIE - Society of Phoito-Optical Instrumentayion Engineers. Washington.

Razif, M. (2018). "Role of Environmental Aspects in Infrastructure and Facility Asset Management". Jurnal Manajemen Aset Infrastruktur \& Fasilitas, Vol. 2, No. 2, September 2018, Hal. : 81-95.

Reis, S.R.N. \& Reis, A.I. (2013). “How to Write Your First Scientific Paper”. Conference Paper - March 2013. ResearchGate, https://www.researchgate.net/publication/236647188.

Soemitro, R.A.A. \& Suprayitno, H. (2018). "Optimization of Loading Arrangement of n Boxes into m Transportation Box". Jurnal Manajemen Aset Infrastruktur \& Fasilitas, Vol. 2, No. 1, Maret 2018, Hal. : 11-21. 
Soemitro, R.A.A. \& Suprayitno, H. (2018a). "Preliminary Reflexion on Basic Concept of Facility Asset Management”. Jurnal Manajemen Aset Infrastruktur \& Fasilitas, Vol. 2, Sup. 1, Juni 2018, Hal. : 1-13.

Sterken, Chris (2006). "Advice on Writting a Sientific Paper". Astrophysics of Variable Stars ASP Conference Series, Vol. 349, 2006.

Suprayitno, Soemitro, R.A.A. (2017). "Preliminary Attempt for Optimizing Transportation Vehicle Number in General Case of Transporting Objects from n Origin Points to 1 Collection Point ". Jurnal Manajemen Aset Infrastruktur \& Fasilitas, Vol. 1, No. 1, Desember 2017, Hal. : 1-10.

Suprayitno, Soemitro, R.A.A. (2018). "Preliminary Reflexion on Basic Principle of Infrastructure Asset Management". Jurnal Manajemen Aset Infrastruktur \& Fasilitas, Vol. 2, No. 1, Maret 2018, Hal. : 1-9.

Suprayitno, Tangahu, B.V. (2018a). "Formulating a Policy for Developing Regional Solid Waste Final Disposal Installation in East Java Province". Jurnal Manajemen Aset Infrastruktur \& Fasilitas, Vol. 2, Sup. 1, Juni 2018, Hal. : 15-25.

Suprayitno, Soemitro, R.A.A. (2018b). "Developing a Framework for Infrastructure Asset Management Knowledge Development by Using Concept Mapping”. Jurnal Manajemen Aset Infrastruktur \& Fasilitas, Vol. 2, No. 2, September 2018, Hal. : 11-20.

Susanti, A., Soemitro, R.A.A. \& Suprayitno, H. (2017). "Simulation Method for Calculating Number of Seat Needed for Ticket Reservation Facilities". Jurnal Manajemen Aset Infrastruktur \& Fasilitas, Vol. 1, No. 1, Desember 2017, Hal. : 23-32.

Susanti, A., Soemitro, R.A.A. \& Suprayitno, H. (2018). "Identification of Station Facilities Needed by Train Passenger Based on Passenger Movement Analysis". Jurnal Manajemen Aset Infrastruktur \& Fasilitas, Vol. 2, No. 1, Maret 2018, Hal. : 23-33.

Upa, V.A., Suprayitno, H. \& Ryansyah, M. (2018).”Comparaison and Synthese of Travel Behavior Characteristics between Trans Mamminasata Bus and Trans Koetaradja Bus Users". Jurnal Manajemen Aset Infrastruktur \& Fasilitas, Vol. 2, No. 2, September 2018, Hal. : 69-81.

Wibisono, E. \& Donny (2018). "Intersection Traffic Performance at Kalen-Majenang due to the Constructuion of Secondary Irrigation Channel of Bengawan Solo River in Kedung Pring Distric, Lamongan". Jurnal Manajemen Aset Infrastruktur \& Lingkungan, Vol. 2, No. 2, September 2018, Hal. : 117-125.

Widiyanti, A., Soemitro, R.A.A., Ekaputri, J.J. \& Suprayitno, H. (2017). "Characterisitcs of Reclaimed Asphalt Metarial form National Roads in East Java Province". Jurnal Manajemen Aset Infrastruktur \& Fasilitas, Vol. 1, No. 1, Desember 2017, Hal. : 11-21.

Widiyanti, A., Soemitro, R.A.A., Ekaputri, J.J. \& Suprayitno, H. (2018). "Performance of Asphalt Concrete Contained Reclaimed Asphalt Pavement from National Road in East Java Province". Jurnal Manajemen Aset Infrastruktur \& Fasilitas, Vol. 2, No. 1, Maret 2018, Hal. : 35-43.

Zanuardi, A. \& Suprayitno, H. (2018). “Analysis of Traffic Accident Analysis on Ahmd Yani Road Surabaya through Knowledge Discovery in Database Approach". Jurnal Manajemen Aset Infrastruktur \& Fasilitas, Vol. 2 No. 1, Maret 2018, Hal. : 45-55.

Ziantono, H.D. \& Suprayitno, H. (2018). "Study of Correlation between Coefficient of Determination with Prediction Error for Certain Sample Size on Trip Production Model in Gresik Urban Area". Jurnal Manajemen Aset Infrastruktur \& Fasilitas, Vol. 2, No. 2, Juni 2018, Hal. : 97-108. 